\title{
Morphological strategies of Cabomba (Cabombaceae), a genus of aquatic plants
}

\author{
Carla Teixeira de Lima ${ }^{1,2}$, Francisco de Assis Ribeiro dos Santos ${ }^{1}$ and Ana Maria Giulietti ${ }^{1}$
}

Received: 28 November, 2013. Accepted: 7 January, 2014

\begin{abstract}
This paper describes the vegetative and reproductive morphology of Cabombaceae species in Brazil, discussing its strategies for survival in an aquatic habitat. Through studies in the field, in cultivation and in the herbarium, we examined the following species: Cabomba aquatica, C. caroliniana, C. furcata and C. haynesii. In cultivation, only C. aquatica, C. furcata and C. haynesii produced flowers. In those three species, the flowers opened during the day on two consecutive days, submerging during the night, although the stigmata of the first two were receptive only on the first day, their anthers dehiscing on the following day. The flowers of $C$. haynesii remained unreceptive on the first day of anthesis, the stigmata and anthers maturing only on the second day, at different times. Fruit developed when the flowers were submerged. The data provided here are useful for the identification of these species, as well as laying the groundwork for future taxonomic and ecological studies.
\end{abstract}

Key words: Brazil, morphology, Nymphaeales, protogyny

\section{Introduction}

The family Cabombaceae is included in the order Nymphaeales and within one of the oldest angiosperm lineages (Borsh et al. 2008). This placement is based on morphological characters, especially floral characters, as well as on molecular data (Cook 1996; Bosch et al. 2008; Taylor et al. 2008).

Cabombaceae includes two genera: Brasenia Schreb., represented solely by B. schreberi Gmel., which has not been recorded for Brazil (Souza \& Lorenzi 2008); and Cabomba Aubl., represented by five species-Cabomba aquatica Aubl., C. caroliniana A. Gray, C. furcata Schult. \& Schult.f., C. haynesii Wiersema and C. palaeformis Fassett-all of which occur in South America (Fassett 1953; Wiersema 1989; Ørgaard 1991; Williamson \& Schneider 1994). Souza \& Lorenzi (2008) recognized three of those species in Brazil, but they do not mention which. Amaral (2010) cited four of the five Cabomba species for Brazil, the exception being $C$. palaeformis. Lima et al. (2012) also cited those four species for the state of Bahia, Brazil. The species of Cabomba are quite similar and difficult to separate.

The present study aims to present morphological descriptions of the vegetative and reproductive parts of Cabomba species. We also discuss the taxonomic characters that aid in the identification of those species and analyze reproductive strategies based on studies of floral biology.

\section{Material and methods}

The specimens of Cabomba aquatic, C. caroliniana, C. furcata and C. haynesii studied here were collected in the state of Bahia, from areas of caatinga (shrublands) and from fragments of Atlantic Forest. Voucher specimens (Table 1) were deposited in the Herbarium of the (Bahia) State University of Feira de Santana (code, HUEFS). To complete the descriptions and aid in the accurate identification of the species, we also analyzed specimens deposited in other herbaria. The herbarium collections examined in Brazil included those of the Alexandre Leal Costa Herbarium of the Federal University of Bahia (code, ALCB); the Herbarium of the Center for Cacao Research (code, CEPEC); the Herbarium of the National Institute for Amazonian Research (code, INPA); the Bradeanum Herbarium (code, HB); the Herbarium of the Federal University of Recôncavo da Bahia (code, HURB); the Herbarium of the Federal University of Vale do São Francisco (code, HVASF); the Herbarium of the Botanical Institute of São Paulo (code, SP); the Herbarium of the University of São Paulo Department of Botany (code, SPF); the Herbarium of the University of Brasília (code, UB); and the Herbarium of the Federal University of (the state of) Goiás. We also examined specimens in the collections of the Berlin-Dahlem Botanical Garden and Museum, in Berlin, Germany (code, B); the Natural History Museum, in London, England (code, BM); the

\footnotetext{
${ }^{1}$ Universidade Estadual de Feira de Santana, Programa de Pós-Graduação em Botânica, Departamento de Ciências Biológicas, Bahia, Brazil

${ }^{2}$ Author for correspondence: carlabotanica@yahoo.com.br
} 
Table 1. Material used in the vegetative morphological and reproductive analysis of the Cabomba taxa studied.

\begin{tabular}{|c|c|c|}
\hline Species & Collector (accession no.) & Collection site \\
\hline \multirow{4}{*}{ Cabomba aquatica Aubl. } & C. T. Lima $(252)^{*}$ & Conde, Rio Cramaí \\
\hline & Guedes, M. L. \& Lima L.S. (10153) & Conde \\
\hline & N. G. Jesus (871) & Alagoinhas \\
\hline & R. M. Harley \& A.M Giulietti et al. (54519) & São Francisco do Conde, Praia do Conde \\
\hline C. caroliniana A. Gray & C. T. Lima \& L.S.P. Lima $(214,340,386)$ & Andaraí, Pantanal de Marimbus \\
\hline \multirow{2}{*}{ C. furcata Schult. \& Schult.f. } & C. T. Lima \& S.G. de Lima $(217,298,301,302,382)^{*}$ & Mata de São João \\
\hline & R. M. Harley et al. (53781) & Formosa do Rio Preto \\
\hline \multirow{5}{*}{ C. haynesii Wiersema } & C. T. Lima \& S.G. Lima $(210,335)^{*}$ & Piritiba \\
\hline & C. T. Lima \& S.G. de Lima (266) & Miguel Calmon \\
\hline & C. T. Lima \& S.G. de Lima $(369)^{*}$ & Candeias \\
\hline & C. T. Lima et al. $(381)^{*}$ & Conde, Rio Cramaí \\
\hline & F. França et al. (5001) & Candeias \\
\hline
\end{tabular}

${ }^{*}$ Materials analyzed in the floral biology studies.

Royal Botanic Gardens, in Kew, England (code, K); the State Herbarium of Munich, in Munich, Germany (code, M); and the Herbarium of the National Museum of Natural History, in Paris, France (code, $\mathrm{P}$ ).

The four species of Cabomba were cultivated in the municipality of Feira de Santana, Bahia. Some plants were cultivated in 1000-L polyethylene tanks, whereas others were cultivated in a $70 \times 50 \times 50 \mathrm{~cm}$ aquarium, which allowed better visualization of the plants. During the study period, three species flowered in cultivation, the exception being C. caroliniana. The illustrations were made with or without the use of a still camera attached to the microscope. We also analyzed the trichomes on the stems.

In the floral biology studies, we recorded the following stages: transition from flower bud to flower in anthesis; flower color; timing of flower opening and closing. For ca. 10 flowers, we counted the pollen grains per anther and multiplied that by the number of stamina per flower. During the two days of anthesis, stigma receptivity was evaluated daily with the (10\%) hydrogen peroxide test. Pollen grain viability was tested with neutral red at $1 \%$. The presence or absence of osmophores was determined by submerging 10 flowers of each species in neutral red (1\%) for $10 \mathrm{~min}$, with subsequent washing in acetic acid at $5 \%$. To determine whether light was required for flower opening, we covered the tank (blocking all light) between 3:00 a.m. and 10:00 a.m. on three randomly selected days.

\section{Results and discussion}

\section{Habit and growth form}

Species of Cabomba are perennial aquatic herbs occurring in fresh standing water or in water with slight currents in lakes or rivers. They propagate mainly by detachment of portions of the stem from the mother plant, with adventitious roots produced in the nodes. The stem is comprised of a horizontal basal portion and an ascendant portion that reaches the surface during flower production (Fig. 1), with branching in several directions, similar to stoloniferous stems. Some authors, including Ørgaard (1991), Wiersema (1989), Williamson \& Schneider (1994) and Feres \& Amaral (2003), have reported the occurrence of a rhizome type of stem in Cabomba. However, we noted that part of the stem runs parallel to the ground, with roots and a continuous ascendant portion, and the stem therefore cannot be characterized as a rhizome or rhizomatous. Francisco \& Barreto (2007) refuted the occurrence of rhizomes in the genus, explaining that there are no differences between aerial parts and underground parts of the stem. Those authors observed that the basal part of the stem sheds its leaves and produces roots when the water level decreases, reporting that when the water level rises, the basal part of the stem changes to a horizontal position begins to produce new branches from each node.

In Cabomba species, the stem has a monopodial growth. It is flexible and erect, with prominent nodes and internodes. In C. furcata, the stem is slightly flattened at the base, cylindrical in the intermediate section and slightly triangular at the apical portion; however, in the three other Cabomba species studied here, the stem is cylindrical (Fig. 2). According to Ørgaard (1991), the stem is fragile, breaks easily and decomposes rapidly, features that were observed in all of the Cabomba species evaluated here, the stem of C. furcata being found to be the most brittle. This is probably due to the presence of large quantities of lacunae that were much larger in size than those observed in the three other species, which hindered the collection of complete herbarium specimens.

In all of the Cabomba species studied here, the stems showed fine, longitudinal striations, which were red in C. aquatica, C. furcata and C. haynesii, whereas they were green in C. caroliniana. According to Ørgaard (1991) the reddish color of the vegetative parts of species of Cabomba is directly related to light intensity, and if the plant is removed 

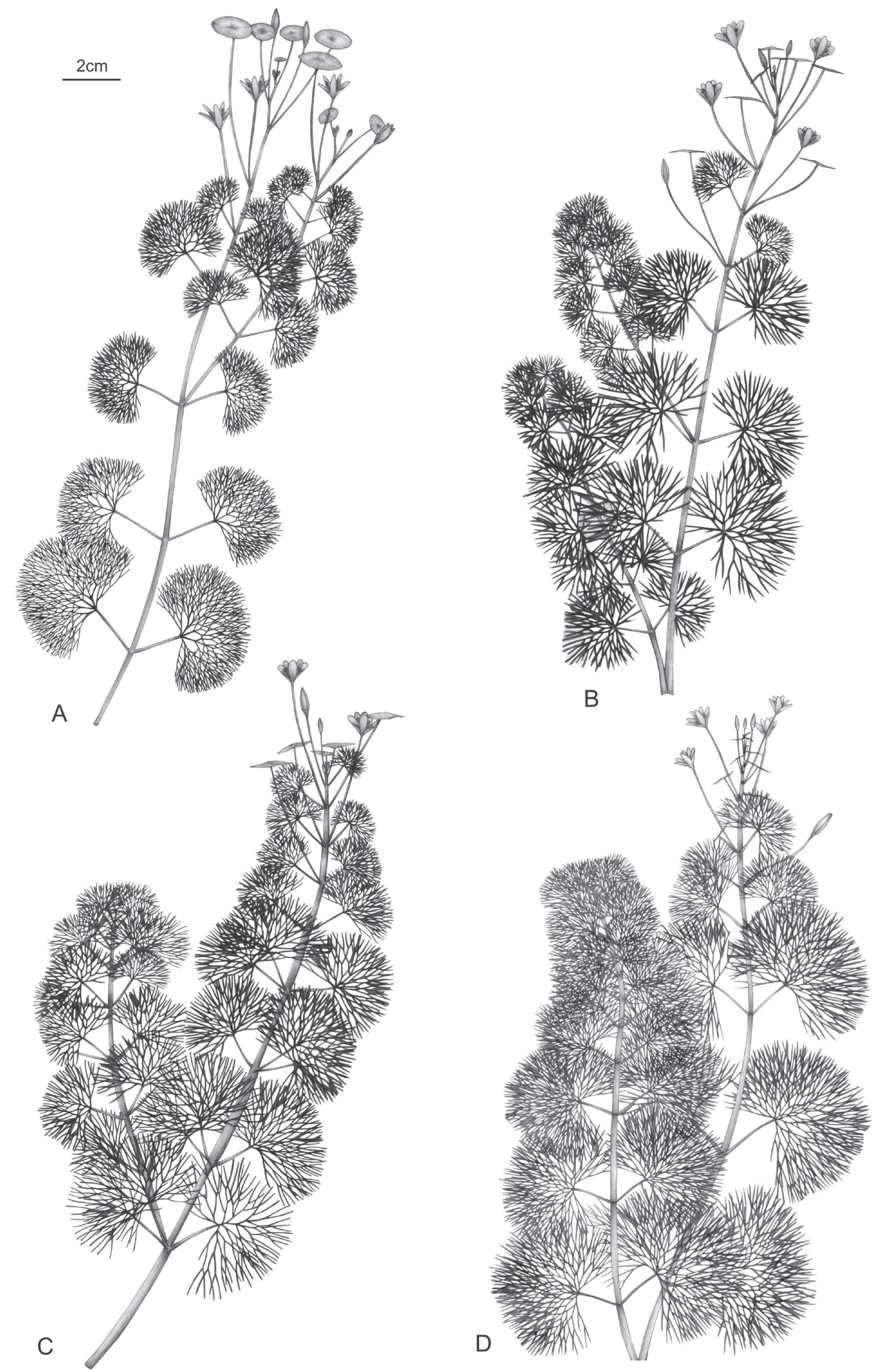

Figure 1. Habit of four species of the genus Cabomba (Cabombaceae): A) C. aquatica, B) C. caroliniana, C) C. furcata and D) C. haynesii. 
to an environment with low light intensity, the older, reddish branches die and all the young branches turn green. However, in the present study, even when the species were cultivated in a low-light environment, their coloration was the same as that observed in the field.

We found that all four of the Cabomba species evaluated presented a pilose stem with multicellular (two- to three-celled) uniseriate trichomes (Fig. 2). These trichomes are believed to be closely related to the release of a layer of mucilage that covers all submerged parts of the plant.

The nodes are prominent as a result of the annularshaped thickening. In C. aquatica, C. furcata and C. haynesii the nodes are reddish colored, due to the presence of red striations and papillae that also occur at the base of the petiole. In C. caroliniana the papillae are green.

The aerial stem may be branched or not, with one or more branches per node. In C. furcata, subsequent internodes are rotated $180^{\circ}$ and three leaves grow from each node.

\section{Leaves}

The leaves of Cabomba are floating or submerged. The floating leaves are temporary and produced solely at the apical parts of the stem, usually accompanying flower production. The first floating leaf often appears at the same node as the apical submerged leaf. The morphology of the floating leaves has generated controversy regarding their role. Ørgaard (1991), Wiersema (1989), Williamson \& Schneider (1994) and Feres \& Amaral (2003) all suggested that the floating leaves aid the flowers in floating. However, Francisco \& Barreto (2007) regard the floating leaves as bracts. Nevertheless, given that the function of these leaves is to help the solitary flowers to float and that we often observed flowers in the axils of the submerged leaves, we prefer to maintain the term floating leaves.

The shape of the blades of the floating leaves is constant and is therefore a useful taxonomic character at the species level. The shape of the leaves is broad-elliptic to orbicular in C. aquatica; narrow-elliptic in C. furcata; and linear in C. caroliniana and C. haynesii. In C. furcata, C. caroliniana and $C$. haynesii there are two branches (arms) of different sizes with an acute apex (Fig. 2J-M). Feres \& Amaral (2003) and Francisco \& Barreto (2007) described the base of the laminae of the floating leaves of C. caroliniana and C. furcata as sagittate. However, considering that the leaf is peltate, with the petiole inserted in the median section of the dorsal side of the leaf and lacking a well-defined base, we describe the leaves of Cabomba as presenting two arms each, arising from the insertion of the petiole, and the terminations as extremities, resembling the branching of the T-shaped trichomes or Malpighiaceous trichomes. The width and length of the arms are characters that help distinguish the various species. In the key to species of Cabomba, Wiersema (1989) and Lima et al. (2012) used the width of the floating leaves to separate C. caroliniana from C. haynesii.
The submerged leaves are simple, palmate-partite; reniform to semi-circular in shape; membranous, crossed and opposite, except in C. furcata, in which they are crossed and 3-verticillate. The petiole is slightly pilose, mainly at the base, becoming glabrescent towards the apex. The lamina is palmate-partite, and has 3-7 primary segments, corresponding to 3-7 actinodromous primary veins. In C. furcata, there are usually three primary segments and in the other species five primary segments. The primary segments are subdivided by successive dichotomous divisions, and the central segment may present divisions of up to the fifth order, the last order originating at the terminal segment. Along the entire margin of the terminal segment, mainly at the apex, there are uniseriate trichomes that are unicellular or bicellular and generally caduceus (Fig. $2 \mathrm{~N}$ Y). Fassett (1953) used the morphology of the segments of the submerged leaves, together with perianth characters, to separate the species. Wiersema (1989) was the first author to give taxonomic importance to the phyllotaxy of submerged leaves. However, the crossed disposition has been reported only in species with opposite phyllotaxy, and here we found that the leaves of $C$. furcata are verticillate and crossed.

The coloration of the petioles and laminae of the submerged leaves is similar to that of the stem. The reddish coloration occurs at the base of the lamina, and is accompanied by small papillae and reddish striations. Striations also occur on the petioles in C. aquatica. In C. furcata, striations occur on the petiole and on all segments of the foliar lamina, producing an intense red coloration, which distinguishes this species from the all others in the genus.

\section{Flower: bud and perianth}

The buds of Cabomba develop underwater, isolated at the apex of the axillary peduncles. The peduncle elongates to allow the ovoid bud, at the beginning of anthesis, to remain submerged and floating with the help of the floating leaves and of the lacunae in the peduncle. After fertilization, the peduncle curves and the flower remains completely submerged throughout the development of the fruit.

The flowers are dichlamydeous, actinomorphic and trimerous; the perianth is marcescent (Fig. 3; Fig. 4A). In C. aquatica and C. haynesii, we observed fewer dimerous flowers per plant. Dimerism reduced the number of stamina in C. aquatica by half (to three), whereas it had no effect on the number of stamina in C. haynesii, which remained at three. Rataj (1977) used a specimen of C. aquatica with dimerous flowers, also with the number of stamina reduced to half, to describe C. schwartzii Rataj. The synonymization of this species was made by Ørgaard (1991), and it was confirmed through analysis of the type material (Schwartz 53905, INPA).

The perianth of Cabomba species is consistent in shape, number and coloration. The sepals are glabrous, petal-like and oblong with a truncate base, except in C. furcata, in 



Figure 2. Morphology of four species of the genus Cabomba (Cabombaceae): A) stem, base of petiole in C. aquatica; B) detail of the stem with trichome in C. aquatica; C) stem, base of petiole in C. caroliniana; D) detail of the stem with trichome in C. caroliniana; E) stem, base of petiole in C. furcata; F) detail of the stem without trichome in C. furcata; G) stem, base of petiole in C. haynesii; H) detail of the stem with trichome in C. haynesii; I) stem; detail of node and root in C. aquatica; J) floating leaf in C. aquatica; K) floating leaf in C. caroliniana; L) floating leaf in C. furcata; M) floating leaf in C. haynesii; N) submerged leaf in C. aquatica; O) primary segment in C. aquatica; P) terminal segment in C. aquatica; Q) submerged leaf in C. caroliniana; R) primary segment in C. caroliniana; S) terminal segment in C. caroliniana; T) submerged leaf in C. furcata; U) primary segment in C. furcata; V) terminal segment in C. furcata; W) submerged leaf in C. haynesii; X) primary segment in C. haynesii; Y) terminal segment in C. haynesii. 



Figure 3. Morphology of four species of the genus Cabomba (Cabombaceae): C. aquatica-A) Flowers, B) Sepal and C) Petal; C. caroliniana-D) Flowers, E) Sepal and F) Petal; C. furcata-G) Flowers) H) Sepal and I) Petal; C. haynesii-J) Flowers; K) Sepal and L) Petal. 
which they are obovate. The petals are ovate in C. aquatica; oblong in C. caroliniana and C. haynesii; and obovate in C. furcata. In all Cabomba species, the petals are unguiculate with an auriculate base, which includes a nectar gland (Fig. 3). The calyx and corolla display the same coloration: yellow in C. aquatica; lilac with a magenta tint in the main veins of $C$. furcata; white in C. caroliniana; and white with a light lilac hue in C. haynesii. Fassett (1953) used the shape of the sepals and petals to separate species within the genus Cabomba. However, Wiersema (1989) considered these characters to be of little taxonomically importance.

\section{Flower: androecium}

In Cabomba species, the androecium has a variable number of stamina: typically six in C. furcata and C. aquatica; four or six in C. caroliniana; and typically three in $C$. haynesii. The filaments are cylindrical and of different sizes according to the day on which the flower opens (Fig. 4B-E). This condition is the result of the gradual growth of the stamen during the two days of anthesis (Williamson \& Schneider 1994; Taylor et al. 2008). The anthers present a strong yellow coloration and are bithecate (tetrasporangiate) and basifixed, with latrorse dehiscence.

\section{Flower: gynoecium}

The gynoecium is apocarpous (one to three carpels), cyclic and yellow, with strigose trichomes nearly $0.1 \mathrm{~mm}$ in length on the ovary and up to the midpoint of the style. The ovary has one to three anatropous ovules, with laminar placentation. The stigmata are capitate, with long and delicate papillae, are whitish and are shiny when receptive (Fig. 4). After fertilization, the stigma becomes blackened and persistent at the apex of the fruit. The number of carpels varies among the species of Cabomba. Hoehne (1948), Caspery (1878) and Ørgaard (1991) described Cabomba gynoecia with up to four carpels.

\section{Floral biology}

We found that, in cultivation, Cabomba aquatica and C. haynesii flowered throughout the year, whereas C. furcata flowered mainly from August to May (in Brazil). These observations are in accordance with the flowering period in nature (see Lima et al. 2012). Although C. caroliniana never flowered in cultivation, it flowers throughout the year in its natural habitat.

In Cabomba aquatica, C. furcata and C. haynesii, the flowers opened during the day on two consecutive days, submerging during the night. However, the stigmata of the first two species were receptive only on the first day and the anthers dehisce on the following day. The flowers of C. haynesii remained unreceptive on the first day of anthesis, the stigmata and anthers maturing only on the second day (at different times).
Over the two days of anthesis, the diameter of the flowers was 7.0-10.5 $\mathrm{mm}$ in Cabomba aquatica, 15.0-18.0 $\mathrm{mm}$ in C. furcata and ca. $10 \mathrm{~mm}$ in C. haynesii. On the first day, the floral peduncle remained $1-2 \mathrm{~cm}$ above the water surface, lifting the bud, in all three species. The flowers began anthesis at ca. 9:30 a.m. in C. aquatica; and at 11:00 a.m. in C. furcata (Fig. 5A). In both of those species, the indehiscent anthers were at the level of the ovary. However, the stigmata were already receptive, and the flowers can therefore be categorized as protogynous. The flowers of C. aquatica and C. furcata closed at 1:30 p.m. and 4:00 p.m., respectively, submerging thereafter (Fig. 5B). In $C$. haynesii, the flowers were in anthesis at ca. 11:20 a.m., although the anthers were indehiscent. Unlike those of the other species, the stigmata of $C$. haynesii were not receptive but already had a plumose appearance, which was maintained throughout the period of flower anthesis, and closed at 1:50 p.m., submerging thereafter (Fig. 5A and 5B). During the winter months (May to August), particularly on cold, rainy days, the flowers opened after 12:00 p.m. and closed at 4:00 p.m.

On the second day of anthesis, the floral peduncle remained $2-3 \mathrm{~cm}$ above the surface of the water (Fig. 6A). In C. aquatica, anthesis began at ca. 8:00 a.m.; first- and second-day flowers completed anthesis approximately at the same time (1:30 p.m.) and submerged thereafter. On rainy days, those events were delayed by ca. $30 \mathrm{~min}$. In C. furcata, second-day flowers opened later (at ca. 10:40 a.m.), although first- and second-day flowers both closed at 4:00 p.m. In C. haynesii, second-day flowers also opened later and closed later, at ca. 10:20 a.m. and 2:40 p.m., respectively (Fig. 5C and 5D). During the winter months, there was also a delay in the timing of second-day anthesis of the flowers of $C$. haynesii, which were not fully open until 11:30 a.m.

When individuals of Cabomba furcata were deprived of light until 10:00 a.m., the beginning of the anthesis was delayed by ca. $4 \mathrm{~h}$. We observed no significant change in the timing of flower opening in C. haynesii after exposure to the same light/dark cycle. It is likely that the flowers of C. furcata open in response to light, whereas the opening of C. haynesii flowers is triggered by temperature, given that the timing of the latter was altered on rainy days and on days that were particularly cold.

First- and second-day flowers of the three species studied here open synchronously. According to Dafni et al. (2005), this behavior plays an important role in attracting floral visitors, because of the visual aspects as well as the concentration of resources.

In addition to visual attractants, flowers of Cabomba species display two auriculate nectar glands at the base of the petals (Fig 3C, 3F, 3I and 3L), providing nectar and pollen grains as rewards for possible pollinators. Within the ANITA grade, the production of nectar has been detected in four families (Cabombaceae, Nymphaeaceae, Schisan- 

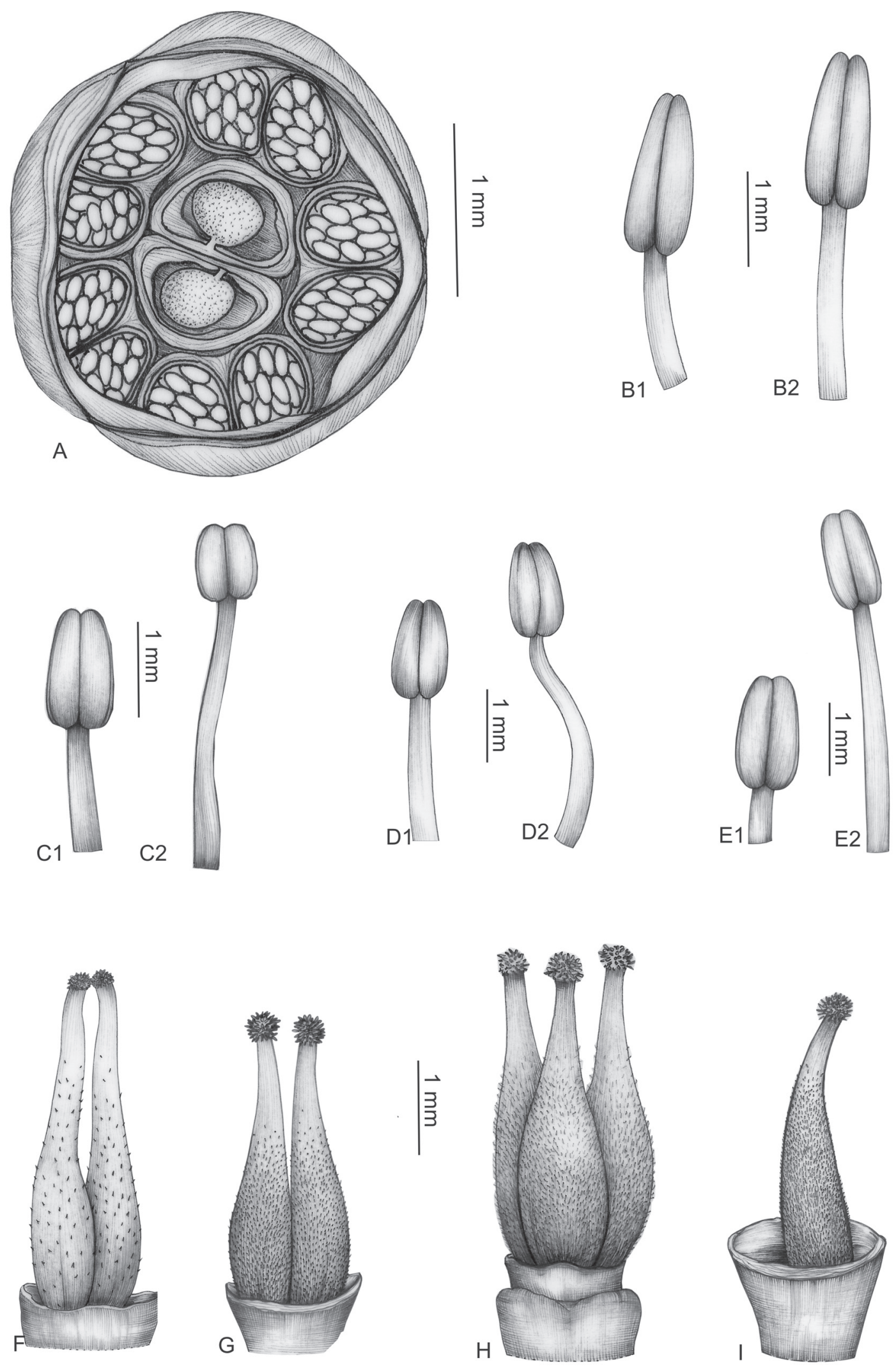

Figure 4. Morphology of four species of the genus Cabomba (Cabombaceae): A) transverse section of first-day flower; stamina of first-day flowers-B1) Cabomba aquatica, C1) C. caroliniana, D1) C. furcata and E1) C. haynesii; stamina of second-day flowers-B2) C. aquatica, C2) C. caroliniana, D2) C. furcata and E2) C. haynesii; gynoecium-F) C. aquatica, G) C. caroliniana, H) C. furcata and I) C. haynesii. 
First day (a.m.)

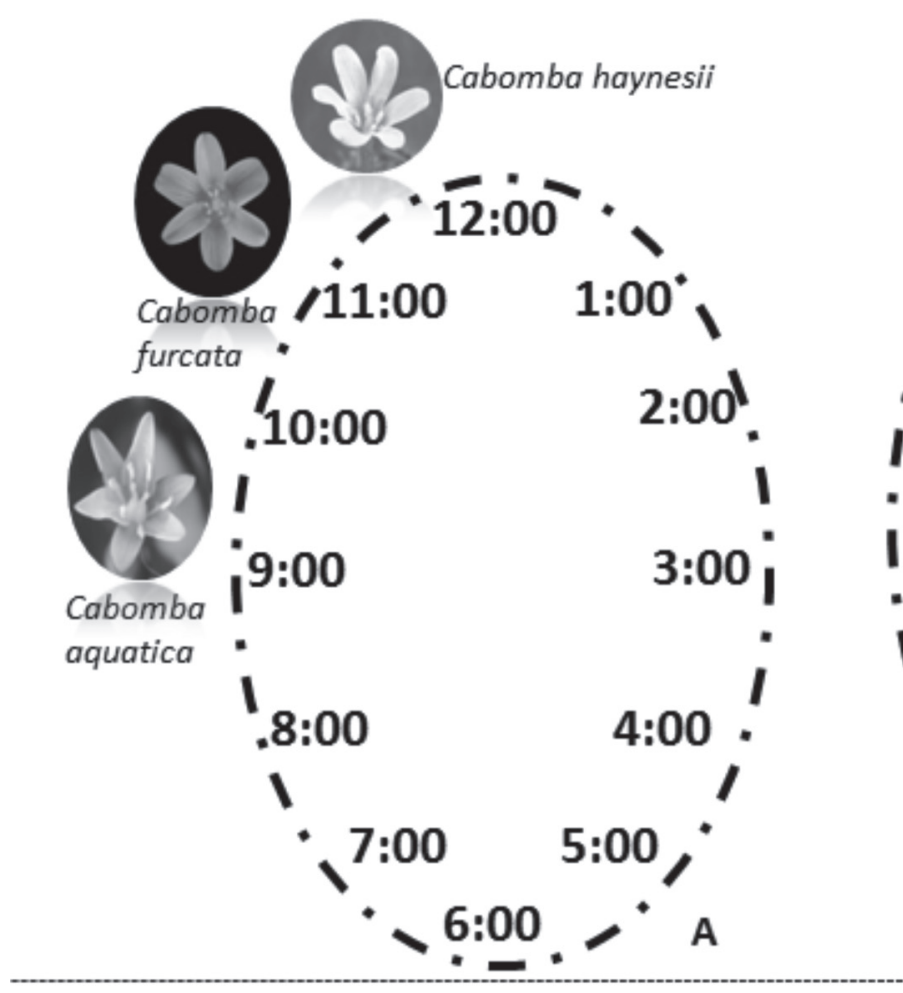

(p.m.)

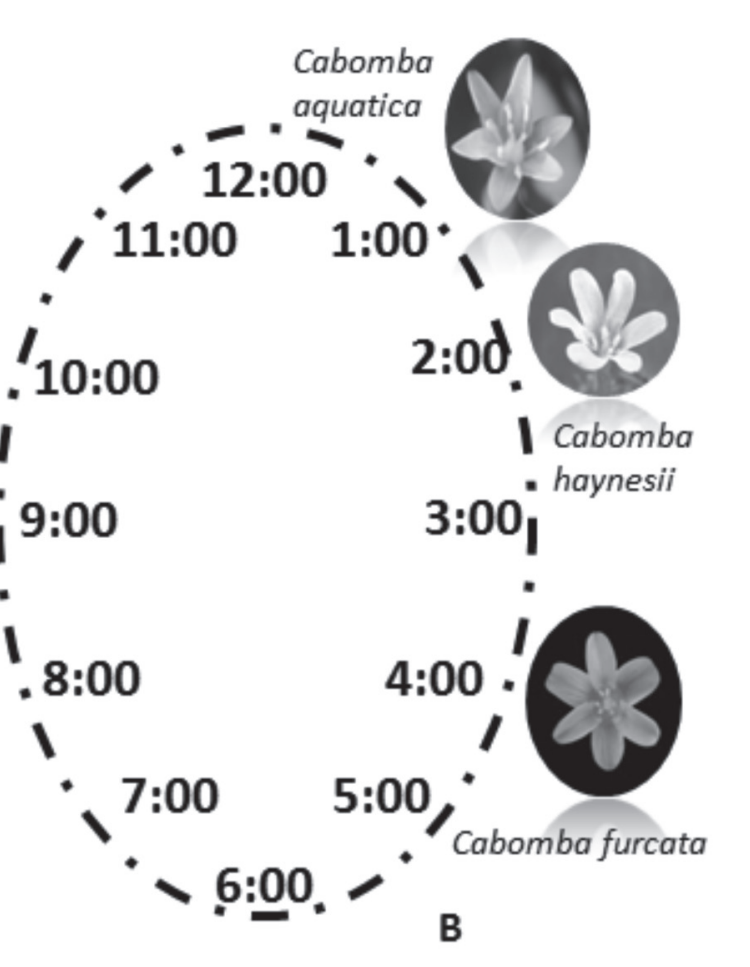

Second day (a.m.)

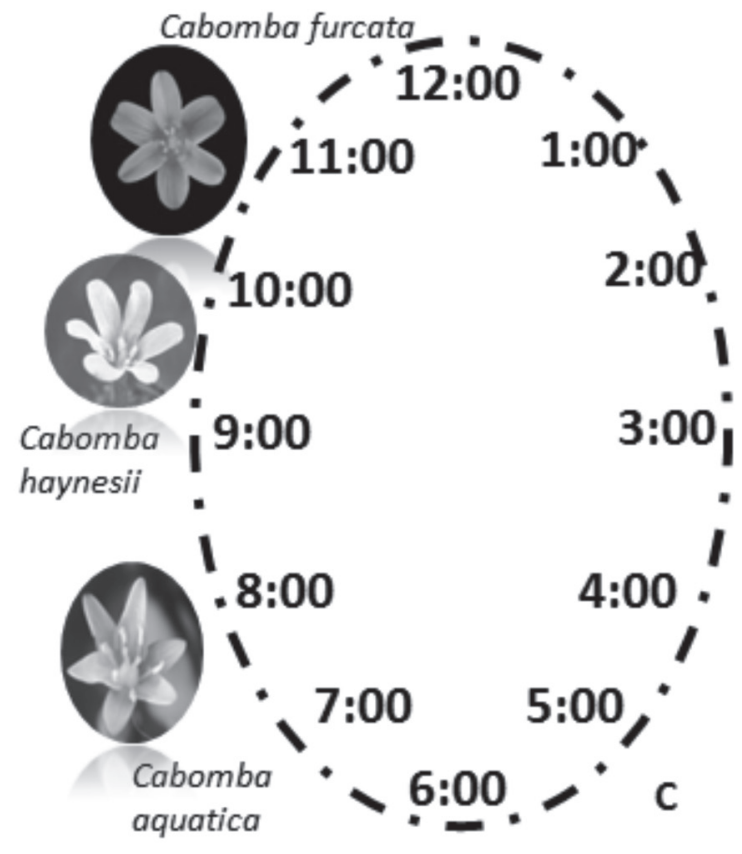

(p.m.)

Cabomba aquatica


2:0b

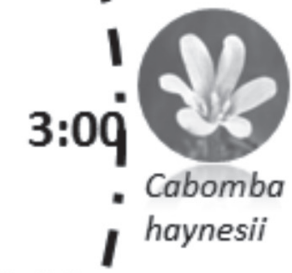

Figure 5. Timing of anthesis of Cabomba aquatic, C. furcata and C. haynesii: A) flower opening on the first day; B) flower closing on the first day; C) flower opening on the second day; D) flower closing on the second day. 
draceae and Illiciaceae), providing compelling evidence of cross-pollination (Thien et al. 2009).

Between the closing of first-day flowers and the opening of second-day flowers, the filaments grew and the stamina increased in length (doubling in some cases), allowing the anthers to be at the same level as the stigma. In Cabomba aquatica, anther dehiscence occurred approximately one hour after the opening of the first-day flowers. In the other two species, that delay was only ca. $20 \mathrm{~min}$. Shortly before the pollen grains were released, the filaments were positioned at an angle of ca. $45^{\circ}$ relative to the carpels, and the position of the anthers was parallel to the water surface, turned towards the perianth. Typically, some anthers remain indehiscent. Cabomba aquatica and C. furcata produce ca. 250 pollen grains per anther, whereas $C$. haynesii produces only ca. 160 grains per anther, which is considered a small quantity of pollen (Cruden 1977). The pollen grains are released as thick massulae. Pollen viability is ca. $98 \%$ in $C$. aquatica, $97 \%$ in C. furcata and $100 \%$ in C. haynesii.

The gynoecium of Cabomba aquatica is typically composed of two carpels, rarely one or three; that of C. furcata has three carpels, rarely two or only one; and that of $C$. haynesii typically has only one carpel. According to Caspary (1878), Hoehne (1948) and Ørgaard (1991), the number of carpels in Cabomba is not consistent among the species, varying from one to four. In the present study, the number of carpels ranged from one to three among the species studied. On the first and second day of anthesis, the style was slightly curved towards the perianth. On the first day of anthesis in C. aquatica and C. furcata, both of which are protogynous, the stigmata of each carpel remained curved towards the perianth and ca. $2 \mathrm{~mm}$ apart, the stigma papillae being elongated and with a shiny appearance (Fig. 6). On the second day of anthesis, the carpels of those two species were closer together, and the papillae begin to wilt rapidly just after the beginning of anthesis on the second day, before anther dehiscence (Fig. 6D, 6F and 6H).

Schneider \& Jeter (1982), Osborn \& Schneider (1988) and Osborn et al. (1991) also categorized species of $\mathrm{Ca}$ bomba as protogynous. However, in the present study, the stigmata of $C$. haynesii were receptive only on the second day of anthesis, despite displaying extended papillae and a shiny appearance on both days of anthesis, being slightly larger on the second day. The need for flowers to open on two consecutive days might be related to the fact that the flowers of C. haynesii are always small and isolated, and anthesis over a period of two days could therefore increase the visible area and attract a greater number of floral visitors. Given that we identified no osmophores in any of the species evaluated, we can assume that the visual features constituted the only attractant for floral visitors.

In Cabomba aquatica, each carpel produces one ovule, multiple ovules (two or three) are rarely observed, and the pollen-ovule ratio is of ca. 1000:1. In C. furcata, each carpel produces two ovules and the pollen-ovule ratio is ca. 300:1.
In C. haynesii, each carpel produces two ovules and the pollen-ovule ratio is ca. 240:1. According to Cruden (1977), C. aquatica is facultatively xenogamous, C. furcata is facultatively autogamous or facultatively xenogamous and $C$. haynesii is facultatively autogamous. However, in the present study, we observed no fruit development, which indicates that Cabomba species require a vector for pollination.

Pollen grains that shed in massulae cannot be transported by wind or water (Thanikaimoni 1986). Together with protogyny and the absence of a pollinator, this could explain the absence of self-pollination in Cabomba species. Pollen grains presented as massulae in C. haynesii would also explain why self-pollination does not occur even when stigmata are receptive and the anthers dehisce on the same day in the absence of a pollinator.

During fruiting, Cabomba species typically develop only one carpel in a follicle-like and indehiscent fruit. The pericarp of each fruit is coriaceous and yellowish, but the seed area is marked and slightly blackened (Fig. 6I-L). In C. aquatica, each fruit typically develops only one seed; in C. furcata, each fruit typically develops two seeds; and in C. haynesii, each fruit typically develops one or two seeds. The shape of the seed varies from oval in C. aquatica and $C$. haynesii to orbicular in C. caroliniana and C. furcata. Seed length also varies, from $\leq 3 \mathrm{~mm}$ in C. caroliniana to $\leq 2 \mathrm{~mm}$ (most $<2 \mathrm{~mm}$ ) in C. furcata (Fig. 6M-P). At maturity, the seeds display a tuberculate testa (with small tubercles arranged longitudinally) and are yellowish with several small red spots. The fruit is protected by a marcescent perianth; the anthocarp detaches from the peduncle and falls to the bottom of the aquatic environment to begin germination, developing a new seedling.

\section{Conclusions}

Species of Cabomba can be distinguished from each other on the basis of their vegetative and reproductive morphology, which generally tends to be consistent between specimens observed in nature and those grown in cultivation. We propose some new terms and morphological characters to describe and distinguish among Cabomba species: "verticillate-crossed" to describe the leaves of $C$. furcata; orbicular leaves in C. aquatica; arms on the side of the laminae of the floating leaves of C. furcata, C. caroliniana and C. haynesii; pollen grains as massulae; and the anthocarp as the dispersal unit.

Protogyny is described as a characteristic feature of Cabomba. However, the absence of protogyny observed in $C$. haynesii signals the development of new reproductive strategies and possibly different interactions with pollinators.

There is a need for further studies involving molecular analyses and evaluating reproductive biology, in order to correlate the different reproductive strategies and evolutionary adaptations within the order Nymphaeales. 



Figure 6. Aspects of floral biology in four species of the genus Cabomba (Cabombaceae). A) difference in peduncle length between first- and second-day flowers in C. haynesii; stigmata of first-day flowers-B) C. aquatica, C) C. caroliniana and E) C. haynesii. stigmata of second-day flowers-D) C. furcata and F) C. haynesii; G) position of stigmata on the first day in C. furcata; H) position of stigmata on the second day in C. furcata; fruit-I) C. aquatica, J) C. caroliniana, K) C. furcata and L) C. haynesii; Seeds-M) C. aquatica, N) C. caroliniana, O) C. furcata and P) C. haynesii. 


\section{Acknowledgments}

We are grateful to the Programa de Pesquisa em Biodiversidade (PPBio, Biodiversity Research Program) of the Brazilian Ministério da Ciência e Tecnologia (MCT, Ministry of Science and Technology) and the Programa de Capacitação em Taxonomia (PROTAX, Program for Training in Taxonomy), for providing assistance with fieldwork; to the program Resgate Histórico e Herbário Virtual para o Conhecimento e Conservação da Flora Brasileira (REFLORA, Historical Rescue and Virtual Herbarium for Advancing the Knowledge and Conservation of the Flora of Brazil), for the opportunity to analyze historical material, as well as the types of Cabomba, deposited at the Herbarium of the Royal Botanic Garden, in Kew, England; to Dr. José Alves Siqueira Filho and the staff of the Centro de Referência Para Recuperação de Áreas Degradadas (CRAD, Referral Center for the Recovery of Disturbed Areas), for their assistance in the field; to Dr. Raymond M. Harley, of the Royal Botanic Garden, for providing the abstract; and to Leandro Soares P. Lima, for helping in the digitalization of the plates. This study received financial support from the Brazilian Coordenação de Aperfeiçoamento de Pessoal de Nível Superior (CAPES, Office for the Advancement of Higher Education; scholarship to CTL) and from the Brazilian Conselho Nacional de Desenvolvimento Científico e Tecnológico (CNPq, National Council for Scientific and Technological Development; research grants to AMG and FARS).

\section{References}

Amaral, M.C. 2010. Cabombaceae. Pp. 821-822. In: Forzza et al. (Eds.) Catálogo de plantas e fungos do Brasil. vol. 1. Rio de Janeiro, Instituto de Pesquisas Jardim Botânico do Rio de Janeiro.

Bosch, T.; Löhne, C. \&Wiersema, J.H. 2008. Phylogeny and evolutionary patterns in Nymphaeales: integrating genes, genomes and morphology. Taxon 57: 1052-1081.

Caspery, R. 1878. Nymphaeaceae. In: C.F.P. Martius (Ed.) Flora Brasiliensis. Monachi. 4(1-2): 120-184.
Cook, C.D.K. 1996. Aquatic Plant Book. Amsterdam, SPB Academic Publishing.

Cruden, R.W. 1977. Pollen-ovule ratios: a conservative indicator of breeding systems in flowering plants. Evolution 31: 32-46.

Dafni, P.G.; Kevan, P.G. \& Husband, B.C. 2005. Practical Pollination Biology. Ontario, Cambridge.

Fassett, N.C. 1953. A Monograph of Cabomba. Castanea 18: 116-128.

Feres, F. \& Amaral, M.C.E. 2003. Cabombaceae. Pp. 9-11. In: Wanderley, M.G.L.; Sherpherd, G.J.; A.M. Giulietti \& Melhem, T.S. (Eds.) Flora Fanerogâmica do Estado de São Paulo. São Paulo, FAPESP/ RiMa.

Francisco, S.L. \& Barreto, V.C. 2007. Cabomba Aubl. (Cabombaceae): caracterização morfoecológica e delimitação entre as espécies ocorrentes no Brasil. Revista Brasileira de Biociências 5: 1077-1079.

Hoehne, F.C. 1948. Plantas Aquáticas. Secretaria da Agricultura de São Paulo, São Paulo.

Lima, C.T.; Giulietti, A.M. \& Santos, F.A.R. 2012. Flora da Bahia: Cabombaceae. Sitientibus. Série Ciências Biológicas. 12: 61-68.

Ørgaard, M. 1991. The genus Cabomba (Cabombaceae) - a taxonomic study. Nordic Journal of Botany 11: 179-203.

Osborn J.M. \& Schneider E.L. 1988. Morphological studies of the Nymphaeaceae sensu lato. XVI. The floral biology of Brasenia schreberi. Annals of the Missouri Botanical Garden 75: 778-794

Osborn, J.M.; T.N. Taylor \& Schneider, E.L. 1991. Pollen morphology and ultrastructure of the Cabombaceae: correlations with pollination biology. American Journal of Botany 78: 1367-1378.

Rataj, K. 1977. Uma nova espécie de Cabomba do rio Negro, Amazonas, Brasil. Acta Amazonica 7(1): 143.

Schneider, E.L. \& Jeter, J.M. 1982. Morphological studies of the Nymphaeaceae. XII. The floral biology of the Cabomba caroliniana. American Journal of Botany 69: 1410-1419.

Souza, V.C. \& Lorenzi, H. 2008. Botânica Sistemática. Guia ilustrado para identificação das famílias de Angiospermas da flora brasileira, baseado em APG II. Instituto Plantarum, Nova Odessa.

Taylor, M.L.; Gutman, B.L.; Melrose, M.A.; Ingraham, A.G.; Schwartz; J.A. \& Orborn, M. 2008. Pollen and anther ontogeny in Cabomba caroliniana $(\mathrm{Ca}-$ bombaceae, Nymphaeales). American Journal of Botany 95(4): 399-413.

Thanikaimoni, G. 1986. Pollen apertures: form and function. Pp. 119-136. In: Blackmore, S. \& Ferguson, I.K. (Eds.). Pollen and spores. Form and functions. London, Academic Press.

Thien, L.B.; Bernhadt, P.; Devsll, B.S.; Chen, Z.; Luo, Y.; Fan, L. \& Williams J.H. 2009. Pollination Biology of Basal Angiosperms (ANITA grade). American Journal of Botany 96(1): 166-182.

Wiersema, J.H. 1989. A new species of Cabomba (Cabombaceae) from Tropical America. Annals of the Missouri Botanical Garden 76(4): 1167-1168.

Williamson, P.S. \& Schneider, E.L. 1994. Cabombaceae. Pp. 157-161. In: Kubitzki, K.; Rohwer, J.G. \& Bittrich, V. (Eds.). The Families and Genera of Vascular Plants. Berlin, Springer-Verlag. 